\title{
Synthesis of Six-Membered Cyclic Carbonate Monomers by Disproportionation of 1,3-Bis(alkoxycarbonyloxy)propanes and Their Polymerization
}

\author{
Gabriel RoKICKI, ${ }^{\dagger}$ Tomasz KowALCZYK, and Marek GLIŃSKI \\ Warsaw University of Technology, Faculty of Chemistry, \\ ul. Noakowskiego 3, 00664 Warsaw, Poland
}

(Received July 21,1999)

\begin{abstract}
A new synthetic method of six-membered cyclic carbonates is presented. Different 1,3-bis(alkoxycarbonyloxy)propanes obtained from 1,3-diols and diethyl or dimethyl carbonate were subjected to disproportionation at 200 $-350^{\circ} \mathrm{C}$ in the presence of colloidal silica or $\mathrm{Sn}(\mathrm{II})$ stearate leading to 1,3-dioxan-2-ones. The disproportionation was carried out in gaseous and liquid phases. The presented method was especially useful for preparation of six-membered mono- and biscyclic carbonates from polyfunctional alcohols such as trimethylolpropane, pentaerythritol and trimethylolpropane dimer. The structure of the polymers obtained from 5-methyl-1,3-dioxan-2-one and 5-ethyl-5methoxycarbonyloxymethyl-1,3-dioxan-2-one in the presence of different catalysts were analyzed using MALDI-TOF mass spectrometry.

KEY WORDS Six-Membered Cyclic Carbonates / Disproportionation of 1,3-Bis(alkoxycarbonyloxy)propanes / Ring Opening Polymerization of Cyclic Carbonates /
\end{abstract}

In recent years a steadily growing interest can be observed for aliphatic cyclic carbonates used as monomers and reagents in polymer synthesis and modification. ${ }^{1-3}$ Especially attractive, seems to be cyclic carbonates application for oligocarbonate synthesis, taking into consideration that polyurethane elastomers obtained from oligocarbonate diols are resistant toward oxidation and hydrolysis. Poly(carbonate-urethane) elastomers are utilized in biomedical practice, where besides good mechanical properties, compatibility with blood is important, e.g., for the production of implanted medical devices. ${ }^{4-6}$ Carbonate copolymers with lactones and lactides exhibit biodegradability and can be easily recycled by thermal depolymerization. ${ }^{7}$ Six-membered cyclic carbonates, similarly to their derivatives-spiroorthocarbonates, as was found by Endo et al., ${ }^{8}$ polymerize with volume expansion. ${ }^{9-12}$

Aliphatic cyclic carbonate monomers, similarly to cyclic bisphenol A oligocarbonates, ${ }^{13}$ can be obtained in a reaction of diols with phosgene, diphosgene or triphosgene. The reaction is usually carried out in the presence of organic or inorganic bases. Instead of phosgene ethyl chloroformate can be used with good effect. ${ }^{14}$ But in these methods toxic reagents and environmentally troublesome side-product $(\mathrm{NaCl})$ produced in stoichiometric amounts are the main drawbacks.

In contrast, transesterification of diols with diethyl or dimethyl carbonates is much more convenient for synthesis of aliphatic cyclic carbonate. Especially, dimethyl carbonate, because of cheap starting materials used for its production (methanol and $\mathrm{CO}$ ),${ }^{15}$ is a useful source of carbonate linkages.

As was shown by Sarel et al. ${ }^{16,17}$ when a small excess (10\%) of dialkyl carbonate was used in transesterification with 1,3-dioles the resulting post-reaction mixture contains mainly linear oligocarbonates, cyclic carbonate and some amount of monoester. In the next step six-

\footnotetext{
${ }^{\dagger}$ To whom correspondence should be addressed
}

membered cyclic carbonates are produced as a result of thermal depolymerization of the oligocarbonates. Crude cyclic carbonates are usually purified by recrystallization from various solvents.

However, as it was found by Kricheldorf et al., ${ }^{18}$ the molecular weight of polycarbonates strongly depends on a solvent used for cyclic monomer crystallization. The crystallization of six-membered cyclic carbonates with low melting point or composed of a mixture of isomers, for example : 5-methyl-1,3-dioxane-2-one (3c), is not sufficient. The fractional distillation is also not effective because of proximity of boiling points of cyclic carbonates and monoesters. Taking the above into consideration it seemed reasonable to use 1,3-bis(alkoxycarbonyloxy)propanes as a starting material for obtaining pure cyclic carbonates. The disproportionation, but of an aromatic bis(methyloxycarbonyloxy) derivative $\left[2,2^{\prime}\right.$-bis(methoxycarbonyloxy)biphenyl] in the presence of $\mathrm{Sn}$ (II) 2ethylhexanoate has also been reported by Kricheldorf et al. ${ }^{19}$

The present work deals with a new method of the synthesis of six-membered cyclic carbonates $(\mathbf{3 a}-\mathbf{3 d})$ by thermal disproportionation of 1,3-bis(alkoxycarbonyloxy)propanes (2a-2d) (Scheme 1) or by using $\mathbf{2 a}-\mathbf{2 d}$ in the reaction with origin 1,3-diols and subsequent distillative depolymerization.

A special interest was devoted to the synthesis of mono- and biscyclic carbonates derived from polyfunctional alcohols by thermal disproportionation of their tris- or tetrakis(alkoxycarbonyloxy) derivatives $(\mathbf{2 f}-\mathbf{2 h})$. In the paper, polymerization of the carbonate monomers of low melting point: 5-methyl-1,3-dioxan-2-one (3c) and 5-ethyl-5-methoxycarbonyloxymethyl-1,3-dioxan-2one $\left(\mathbf{3 f m}^{*}\right)$ initiated by anionic, cationic and enzymatic catalysts is also discussed.

\footnotetext{
* Second letter in the carbonate symbol ( $\mathbf{m}$ or $\mathbf{e})$ means: $\mathrm{R}=$ methyl or ethyl group, as was shown in Scheme 1.
} 


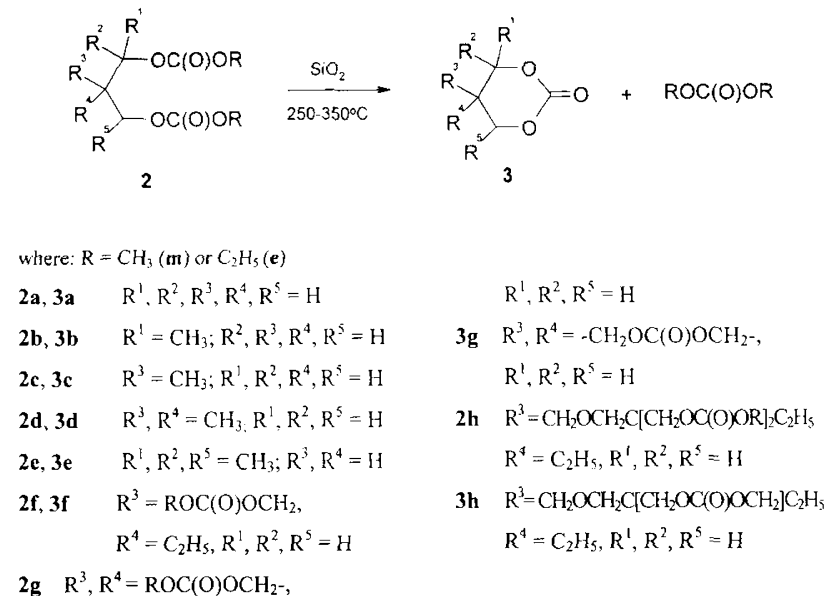

Scheme 1.

\section{EXPERIMENTAL}

\section{Materials}

Diethyl and dimethyl carbonates, propane-1,3-diol, 2methylpropane-1,3-diol, neopentyl glycol, pentane-2,4diol, 2-methylpentane-2,4-diol (Aldrich) were purified by distillation. Pentaerythritol, trimethylolpropane, dimer of trimethylolpropane (Aldrich) were used without additional purification. $\mathrm{BF}_{3} \cdot \mathrm{OEt}_{2}$ (Merck) was used after distillation. Commercial alumina (type C, $100 \mathrm{~m}^{2} \mathrm{~g}^{-1}$ ) and silica (Aerosil 200, $200 \mathrm{~m}^{2} \mathrm{~g}^{-1}$ ) were supplied by Degussa. Immobilized on a macroporous acrylic resin lipases from Candida antarctica (Novozym 435) was a gift from Novo Nordisk Bioindustrials, Inc. Tin (II) stearate was synthesized form $\mathrm{Sn}$ (II) octanoate in the reaction with stearic acid and subsequent removing octanoic acid under reduced pressure.

\section{Measurements}

${ }^{1} \mathrm{H} N M R$ and ${ }^{13} \mathrm{C}$ NMR spectra were recorded on a Varian VXR $300 \mathrm{MHz}$ spectrometer. Deuterated solvents were used and tetramethylsilane served as internal standard.

IR spectra were recorded on Specord $71 \mathrm{R}$ or Biorad FT-IR spectrometers as $\mathrm{KBr}$ pellets. Gas chromatography combined with mass spectrography (GCMS) analyses were carried out using Hewlett-Packard MS-5971 and GC 5890-2 apparatuses. Disproportionation products were analyzed by GC Gas-Chrom $Q$ equipped with 20\% OV-101 column and FID detector. Polycarbonate MALDI-TOF spectra were recorded on a Kratos Kompact MALDI 4 V5.2.1 apparatus using dihydroxybenzoic acid as a matrix.

\section{Synthesis of 1,3-Bis(ethoxycarbonyloxy)-2-methylpropane (2ce)}

In a three neck flask of $500 \mathrm{~cm}^{3}$ equipped with a mechanical stirrer, thermometer, and distillation column (80 cm length) $22.5 \mathrm{~g}(0.25 \mathrm{~mol})$ of 2-methylpropane-1,3diol (1c), $236 \mathrm{~g}$ (2 mol) of diethyl carbonate and $0.2 \mathrm{~g}$ of anhydrous potassium carbonate were placed and heated using thermostated oil bath. The bath temperature was continuously raised to $130^{\circ} \mathrm{C}$, while ethanol-containing $c a .5 \%$ of diethyl carbonate was distilled off. The reaction was carried out as far as there was no absorption band at $3300-3800 \mathrm{~cm}^{-1}$ characteristic for $\mathrm{OH}$ groups in the IR spectrum of the reaction mixture $(3-4 \mathrm{~h})$. Then, the catalyst was removed by decantation and additional stirring ( $12 \mathrm{~h}$ r.t.) with ion exchange resin (Amberlit IR124). After that, the excess of diethyl carbonate was distilled off and the product analyzed using GC-MS apparatus. Then $0.5 \mathrm{~g}$ of $\mathrm{Sn}$ (II) stearate was added and the flask content heated at $160^{\circ} \mathrm{C}$ for $2 \mathrm{~h}$ to polymerize cyclic carbonates. The resulting mixture was subjected to vacuum distillation $\left(145-155^{\circ} \mathrm{C} / 0.5-0.8 \mathrm{mmHg}\right)$ and $38 \mathrm{~g}$ of 1,3-bis (ethoxycarbonyloxy)-2-methylpropane (2ce) were collected ( $63 \%$ yield).

${ }^{1} \mathrm{H} \mathrm{NMR}\left(\mathrm{CDCl}_{3}\right): \delta(\mathrm{ppm})=1.10\left(\mathrm{~d}, 3 \mathrm{H}, \mathrm{CH}_{3}\right), 1.20(\mathrm{t}$, $6 \mathrm{H}, \mathrm{CH}_{3} \mathrm{CH}_{2}$ ), 2.18-2.28 (m, $\left.1 \mathrm{H}, \mathrm{CH}\right), 4.05-4.15(\mathrm{~m}$, $8 \mathrm{H}, \mathrm{CHCH}_{2}$ and $\left.\mathrm{CH}_{3} \mathrm{CH}_{2}\right)$.

FT-IR (KBr) : 2900, 1748, 1480, 1390, 1265, 1100, 860, $770 \mathrm{~cm}^{-1}$

In the case of 1e instead of 1,3-bis(ethoxycarbonyloxy) derivative the crystals of cyclic carbonate $\mathbf{3 e}(\mathrm{mp} 98-$ $99^{\circ} \mathrm{C}$, lit. $96^{\circ} \mathrm{C}^{20}$ ) were almost exclusively formed (yield 97\%).

${ }^{1} \mathrm{H} \mathrm{NMR}\left(\mathrm{CDCl}_{3}\right): \delta(\mathrm{ppm})=1.34\left(\mathrm{~d}, 3 \mathrm{H}, \mathrm{CH}_{3}\right), 1.39(\mathrm{~s}$, $\left.6 \mathrm{H}, \mathrm{CH}_{3}\right), 1.68\left(\mathrm{dd}, 1 \mathrm{H}_{\mathrm{a}}, \mathrm{CH}_{2}\right), 1.92\left(\mathrm{dd}, 1 \mathrm{H}_{\mathrm{e}}, \mathrm{CH}_{2}\right), 4.52$ $-4.63\left(\mathrm{~m}, 1 \mathrm{H}, \mathrm{CH} \mathrm{CH}_{3}\right)$.

FT-IR (KBr) : 2932, 1725, 1382, 1280, 1210, 1130, 760 $\mathrm{cm}^{-1}$.

Reaction of 2-Methylpropane-1,3-diol (1c) with Diethyl Carbonate Carried Out without Removing Ethanol Form the System

Reaction of $1 \mathrm{c}(22.5 \mathrm{~g}, 0.25 \mathrm{~mol})$ with diethyl carbonate $(236 \mathrm{~g}, 2 \mathrm{~mol})$ in the presence of anhydrous $\mathrm{K}_{2} \mathrm{CO}_{3}$ $(0.2 \mathrm{~g})$ was carried out at reflux for $12 \mathrm{~h}$. Then, ethanol and the excess diethyl carbonate were distilled off. $42 \mathrm{~g}$ of $2 \mathrm{ce}$ ( $70 \%$ yield) were obtained.

Synthesis of 1,3-Bis(methoxycarbonyloxy)-2-methylpropane (2cm)

$18 \mathrm{~g}(0.2 \mathrm{~mol})$ of $1 \mathrm{c}, 189 \mathrm{~g}$ ( $1.6 \mathrm{~mol})$ of dimethyl carbonate and $0.1 \mathrm{~g}$ of anhydrous potassium carbonate were placed and heated using thermostated oil bath. The bath temperature was continuously raised to $120^{\circ} \mathrm{C}$, while methanol was distilled off. The reaction was carried out for $6 \mathrm{~h}$ until all hydroxyl groups were reacted. $22.2 \mathrm{~g}$ ( $54 \%$ yield) of $2 \mathrm{~cm}$ were collected by fractional distillation $\left(125-128^{\circ} \mathrm{C} / 0.5-0.7 \mathrm{mmHg}\right)$.

${ }^{1} \mathrm{H} \mathrm{NMR}\left(\mathrm{CDCl}_{3}\right): \delta(\mathrm{ppm})=1.12\left(\mathrm{~d}, 3 \mathrm{H}, \mathrm{CH}_{3}\right), 2.20-$ $2.28(\mathrm{~m}, 1 \mathrm{H}, \mathrm{CH}), 3.70\left(\mathrm{~s}, 6 \mathrm{H}, \mathrm{CH}_{3} \mathrm{O}\right), 4.05\left(\mathrm{~d}, 4 \mathrm{H}, \mathrm{CH}_{2}\right.$ $\mathrm{OCO}_{2}$ ).

FT-IR (KBr) : 2900, 1745, 1440, 1252, 945, 890, 770 $\mathrm{cm}^{-1}$.

Thermal Disproportionation of 1,3-Bis(ethoxycarbonyloxy)-2-methylpropane (2ce)

Reaction in Gaseous Phase. The powders of alumina (type C, $100 \mathrm{~m}^{2} \mathrm{~g}^{-1}$ ) and silica (Aerosil 200, $200 \mathrm{~m}^{2} \mathrm{~g}^{-1}$ ) were mixed with redistilled water and the resulting gels were dried at $60^{\circ} \mathrm{C}$ and $120^{\circ} \mathrm{C}$ for $24 \mathrm{~h}$. The catalysts were prepared by impregnation of the supports $\left(0.5^{--1.0}\right.$ $\mathrm{mm}$ grain diameter) with aqueous solutions of precur- 
sors $\left(\mathrm{NH}_{4} \mathrm{Mo}_{7} \mathrm{O}_{24} \cdot 2 \mathrm{H}_{2} \mathrm{O}, \mathrm{NH}_{4} \mathrm{VO}_{3}\right)$ using the incipient wetness technique. Hydrogen peroxide $(30 \mathrm{v} / \mathrm{v} \%)$ was added into the aqueous suspension of precursors to increase their solubility. The impregnated samples were dried at $120^{\circ} \mathrm{C}$ for $12 \mathrm{~h}$ and then calcined at $450^{\circ} \mathrm{C}$ for $3 \mathrm{~h}$ in a stream of air. The disproportionation reaction was carried out in a typical quartz reactor with $1 \mathrm{~g}$ of the catalyst. 1,3-Bis (ethoxycarbonyloxy)propanes were dosed using a microdosing pump with liquid space velocity (LHSV) $2 \mathrm{~cm}^{3} \mathrm{~g}^{-1} \mathrm{~h}^{-1}$. The reaction products were analyzed by GC and identified by comparing the retention time with that of an authentic sample. $n$-Decane or $n$-dodecane were used as internal standards.

Reaction in Liquid Phase. $50 \mathrm{~g}(0.21 \mathrm{~mol})$ of $2 \mathrm{ce}$ and 2 $\mathrm{g}$ of colloidal silica of the surface area $200 \mathrm{~m}^{2} \mathrm{~g}^{-1}$ (Aerosil 200) were placed in a distillation flask and heated at $190-220^{\circ} \mathrm{C}$ under reduced pressure $(40$ $\mathrm{mmHg}$ ) and diethyl carbonate as a by-product was distilled off. After thermal disproportionation completion the flask content was heated at $250-270^{\circ} \mathrm{C}$ under reduced pressure and 5-methyl-1,3-dioxan-2-one was collected as the fraction boiling at $100-105^{\circ} \mathrm{C} / 0.5 \mathrm{mmHg}$ (lit. $\left.90-91^{\circ} \mathrm{C} / 0.75 \mathrm{mmHg}^{20}\right) .10 .2 \mathrm{~g}$ ( $44 \%$ yield) of $\mathbf{3 c}$ were obtained. ${ }^{1} \mathrm{H} \mathrm{NMR}\left(\mathrm{CDCl}_{3}\right): \delta(\mathrm{ppm})=0.76(\mathrm{~d}, 3 \mathrm{H}$, $\left.\mathrm{CH}_{3}\right), 2.02-2.17(\mathrm{~m}, 1 \mathrm{H}, \mathrm{CH}), 3.77-3.85$ and $4.09-4.15$ (dd, $\left.\mathrm{H}_{\mathrm{e}}, \mathrm{H}_{\mathrm{a}} 4 \mathrm{H}, \mathrm{CH}_{2} \mathrm{O}\right)$. FT-IR (KBr) : 2920, 1746, 1465, $1400,1218,1155,1109,770 \mathrm{~cm}^{-1}$. In a similar manner 3b (bp $161-164^{\circ} \mathrm{C} / 18 \mathrm{mmHg}$, lit. $163^{\circ} \mathrm{C} / 17 \mathrm{mmHg}^{20}$ ) was obtained ( $18 \%$ yield).

Synthesis of 5-Methyl-1,3-dioxan-2-one (3c) from 1,3-Bis(ethoxycarbonyloxy)-2-methylpropane (2ce) and 2Methylpropane-1,3-diol (1c)

$29.3 \mathrm{~g}(0.125 \mathrm{~mol})$ of $2 \mathrm{ce}$ and $11.3 \mathrm{~g}(0.125 \mathrm{~mol})$ of $1 \mathrm{c}$ were reacted in the presence of $2.1 \mathrm{~g}(2.5 \mathrm{mmol} \%)$ of tin (II) stearate at $170^{\circ} \mathrm{C}$ while ethanol was distilled off as a by-product. Next, the pressure was reduced $(3 \mathrm{mmHg})$ and condensation was continued as far as ethanol elimination stopped. Thus, at $200-220^{\circ} \mathrm{C}$ distillative depolymerization of the resultant mixture was carried out and $29 \mathrm{~g}$ (yield $80 \%$ ) of $3 \mathrm{c}$ were collected.

Other cyclic carbonates of 1,3 -diols were obtained in a similar manner.

\section{Synthesis of 5-Ethyl-5-ethoxycarbonyloxymethyl-1,3-dioxan- 2-one (3fe)}

The Disproportionation Method. Transesterification of trimethylolpropane (TMP) (1f) (33.5 g, $0.25 \mathrm{~mol})$ and diethyl carbonate $(354 \mathrm{~g}, 3 \mathrm{~mol})$ was carried out in the presence of anhydrous $\mathrm{K}_{2} \mathrm{CO}_{3}(0.4 \mathrm{~g}, 3 \mathrm{mmol})$ at 110 $130^{\circ} \mathrm{C}$. After the reaction completion an excess of diethyl carbonate was distilled off, and the resulting 1,1,1-tris(ethoxycarbonyloxymethyl)propane (2fe) was collected as the fraction boiling at $162-170^{\circ} \mathrm{C} / 0.8-1.0 \mathrm{mmHg} .41$ $\mathrm{g}(0.12 \mathrm{~mol})$ of $2 \mathrm{fe}$ and $2 \mathrm{~g}$ of Aerosil 200 were placed in a distillation flask and heated at $200-220^{\circ} \mathrm{C}$ under reduced pressure $(40 \mathrm{mmHg})$ and diethyl carbonate as a side-product was removed by distillation. After thermal disproportionation was finished the oligocarbonate derivative of TMP was subjected to distillative depolymerization and 5-ethyl-5-ethoxycarbonyloxymethyl-1,3dioxan-2-one (3fe) was distilled off under reduced pressure $\left(250-270^{\circ} \mathrm{C} / 0.1 \mathrm{mmHg}\right)$ and collected in a cooled receiver. $18 \mathrm{~g}$ (yield $30 \%$, calculated on TMP) of the distillate, which comprises 3 fe to the extent $95 \%$, were obtained.

GCMS : $\mathrm{m} / \mathrm{z}=233 \quad\left(\mathrm{M}+\mathrm{H}^{+}\right) .{ }^{1} \mathrm{H}$ NMR $\quad\left(\mathrm{CDCl}_{3}\right): \delta$ $(\mathrm{ppm})=0.82\left(\mathrm{t}, 3 \mathrm{H}, \mathrm{CH}_{3} \mathrm{CH}_{2} \mathrm{C}\right), 1.19\left(\mathrm{t}, 3 \mathrm{H}, \mathrm{CH}_{3} \mathrm{CH}_{2} \mathrm{O}\right)$, 1.43 (q, 2H, $\left.\mathrm{CCH}_{2} \mathrm{CH}_{3}\right), 4.04\left(\mathrm{~s}, 2 \mathrm{H}, \mathrm{CCH}_{2} \mathrm{O}\right), 4.08$ (q, 2H, $\left.\mathrm{OCH}_{2} \mathrm{CH}_{3}\right), 4.11\left(\mathrm{~d}, 2 \mathrm{H}_{\mathrm{a}}, \mathrm{CH}_{2} \mathrm{O}\right), 4.19\left(\mathrm{~d}, 2 \mathrm{H}_{\mathrm{e}}, \mathrm{CH}_{2} \mathrm{O}\right)$. FTIR (KBr) : 2910, 1750, 1470, 1400, 1250, 1165, 1100, $770,752 \mathrm{~cm}^{-1}$.

The Two-Step Method. $40.0 \mathrm{~g}(0.12 \mathrm{~mol})$ of $2 \mathrm{fe}$ obtained according to the above mentioned method and $8 \mathrm{~g}$ $(0.06 \mathrm{~mol})$ of TMP were subjected to transesterification with one another in the presence of $0.04 \mathrm{~g}(0.17 \mathrm{mmol})$ of dibutyltin oxide at $155-160^{\circ} \mathrm{C}$ under reduced (25 $\mathrm{mmHg}$ ) pressure and ethanol formed as a side-product was distilled off. Thus, the resulting oligocarbonate derivatives of TMP was introduced continuously from a hot $\left(120^{\circ} \mathrm{C}\right)$ dropping funnel into a $0.2 \mathrm{dm}^{3}$ flask heated to $250-280^{\circ} \mathrm{C}$ and evacuated to $0.5 \mathrm{mmHg}{ }^{21} 3$ fe, formed by cleavage of the oligomer, was distilled off and collected in a cooled receiver. $27 \mathrm{~g}$ (yield $50 \%$ ) of the distillate, which comprised 3fe to the extent ca. $96 \%$ and $2-$ $3 \%$ of TMP, were obtained.

\section{Synthesis of Biscyclic Carbonate of Pentaerythritol (3g)}

Transesterification of pentaerythritol (1 $\mathbf{g})(17 \mathrm{~g}, 0.125$ mol) and diethyl carbonate ( $236 \mathrm{~g}, 2 \mathrm{~mol}$ ) was carried out in the presence of dibutyltin oxide $(0.5 \mathrm{~g}, 2 \mathrm{mmol})$ at 110 $130^{\circ} \mathrm{C}$ until $\mathrm{OH}$ groups disappearing. After evaporation of an excess of diethyl carbonate the flask content [mainly tetrakis (ethoxycarbonyloxymethyl) methane (2ge)] was subjected to the thermal disproportionation $\left(200-220^{\circ} \mathrm{C}\right)$ and subsequent distillative depolymerization $\left(220-270^{\circ} \mathrm{C}\right)$ collecting, under vacuum $(0.1 \mathrm{mmHg})$ $3 \mathrm{~g}$ (yield $12 \%$ ) of biscyclic carbonate of pentaerythritol (2,4,8,10-tetraoksa[5,5]undekan-3,9-dion) (3g). Mp 117 $-118^{\circ} \mathrm{C}$ (after recrystallization from $\mathrm{CH}_{2} \mathrm{Cl}_{2}$ ), (lit. 222$228^{\circ} \mathrm{C}$, decomp. ${ }^{22}$ ).

${ }^{1} \mathrm{H} \mathrm{NMR}\left(\mathrm{CDCl}_{3}\right): \delta(\mathrm{ppm})=4.59\left(\mathrm{~d}, 4 \mathrm{H}_{\mathrm{a}}, \mathrm{CH}_{2}\right), 4.60$ (d, $4 \mathrm{H}_{\mathrm{e}}, \mathrm{CH}_{2}$ ).

${ }^{13} \mathrm{C} \mathrm{NMR}\left(\mathrm{CDCl}_{3}\right): \delta(\mathrm{ppm}) 36.11 \mathrm{C}_{\mathrm{q}}, 72.60$ and 75.60 $\mathrm{CH}_{2}, 147.50 \mathrm{C}=\mathrm{O}$.

FT-IR (KBr) : $2900,1755,1260,1090,758 \mathrm{~cm}^{-1}$.

\section{Synthesis of Biscyclic Carbonate of the Trimethylolpro-} pane Dimer (3h)

Synthesis of biscyclic carbonate of the trimethylolpropane dimer $(\mathbf{3 h})$ was carried out similarly to that of $\mathbf{3 g}$. 3h was obtained with yield of $8 \%, \mathrm{mp} 100-102^{\circ} \mathrm{C}$ (after recrystallization from tetrahydrofuran (THF)).

${ }^{1} \mathrm{H} \mathrm{NMR}\left(\mathrm{CDCl}_{3}\right): \delta(\mathrm{ppm})=0.884\left(\mathrm{t}, 6 \mathrm{H}, \mathrm{CH}_{3} \mathrm{CH}_{2}\right)$, 1.463 (q, $4 \mathrm{H}, \mathrm{CH}_{2} \mathrm{CH}_{3}$ ), 3.468 (s, $4 \mathrm{H}, \mathrm{CH}_{2} \mathrm{OCH}_{2}$ ), 4.147 (d, $4 \mathrm{H}_{\mathrm{a}}, \mathrm{CH}_{2} \mathrm{OCO}_{2}$ ), 4.254 (d, $4 \mathrm{H}_{\mathrm{e}}, \mathrm{CH}_{2} \mathrm{OCO}_{2}$ ).

FT-IR (KBr) : $2973,1745,1198,1115,757 \mathrm{~cm}^{-1}$

\section{Ring-Opening Polymerization of $\mathbf{3 c}$ and $\mathbf{3 f}$}

A glass ampoule was heated in vacuum before use, filled with dry nitrogen, and handled in a stream of dry nitrogen. To $14.8 \mathrm{mmol}$ of $\mathbf{3 c}, \mathbf{3 d}$, or $3 \mathbf{f}$ catalyst of $0.5-$ $1 \mathrm{~mol} \%\left(\mathrm{BF}_{3} \cdot \mathrm{OEt}_{2}, \mathrm{~K}_{2} \mathrm{CO}_{3}\right.$ or $\left.\mathrm{SnOct}_{2}\right)$ was introduced, ampoule sealed and immersed into a thermostated oil bath $\left(80-120^{\circ} \mathrm{C}\right)$. After cooling the reaction product was dissolved in $\mathrm{CH}_{2} \mathrm{Cl}_{2}$, filtered and precipitated into cold 
methanol.

Poly(2-methylpropane-1,3-diol carbonate) obtained in the presence of $\mathrm{BF}_{3} \cdot \mathrm{OEt}_{2}:{ }^{1} \mathrm{H} \mathrm{NMR}\left(\mathrm{CDCl}_{3}\right): \delta(\mathrm{ppm})=$ $0.94-0.95\left(\mathrm{~d}, \mathrm{CH}_{3}\right), 0.97-0.98\left(\mathrm{~d}, \mathrm{CH}_{3}\right) 1.01\left(\mathrm{~d}, \mathrm{CH}_{3}\right)$, $1.79-2.12(\mathrm{~m}, \mathrm{CH}), 2.16-2.27(\mathrm{~m}, \mathrm{CH}), 3.30-3.33(\mathrm{~d}$, $\mathrm{CH}_{2} \mathrm{OCH}_{2}$ ), $3.55\left(\mathrm{~m}, \mathrm{CH}_{2} \mathrm{OH}\right), 4.07$ (d, $\mathrm{CH}_{2} \mathrm{OCO}$ ). FT-IR $(\mathrm{KBr}): 2926,1750,1470,1400,1220,1160,1110,770$ $\mathrm{cm}^{-1}$.

Poly(2-ethyl-2-methoxycarbonyloxymethylpropane-1,3diol carbonate) obtained in the presence of $\mathrm{K}_{2} \mathrm{CO}_{3}:{ }^{1} \mathrm{H}$ $\mathrm{NMR}\left(\mathrm{CDCl}_{3}\right): \delta(\mathrm{ppm})=0.92\left(\mathrm{t}, \mathrm{CH}_{3}\right), 1.51\left(\mathrm{q}, \mathrm{CH}_{2}\right.$ $\mathrm{CH}_{3}$ ), $3.77\left(\mathrm{~s}, \mathrm{CH}_{3} \mathrm{OCO}_{2}\right), 4.12\left(\mathrm{~s}, \mathrm{CH}_{2} \mathrm{OCO}_{2}\right)$ (Figure 5).

\section{Enzymatic Ring-Opening Polymerization of $3 \boldsymbol{c}$}

For bulk polymerization a mixture of $10 \mathrm{mg}$ of Novozym 435 ( $1 \%$ concentration of immobilized lipase corresponds to approximately $0.05 \%$ lipase based on the monomer) and $1 \mathrm{~g}$ of $3 \mathbf{c}$ were shaken in an nitrogen atmosphere in a sealed ampoule placed in a thermostated oil bath at $60^{\circ} \mathrm{C}$ for $120 \mathrm{~h}$. After the reaction completion, the mixture was dissolved in chloroform $(5 \mathrm{~mL})$, and immobilized enzyme was removed by filtration. Chloroform was then evaporated under reduced pressure. The monomer conversion was determined by ${ }^{1} \mathrm{H}$ NMR spectroscopy. $0.56 \mathrm{~g}$ (yield $56 \%$ ) of poly $(3 \mathrm{c})$ was obtained.

${ }^{1} \mathrm{H} \mathrm{NMR}\left(\mathrm{CDCl}_{3}\right): \delta(\mathrm{ppm})=1.01\left(\mathrm{~d}, \mathrm{CH}_{3}\right), 2.16-2.27$ (m, CH), $3.55\left(\mathrm{~m}, \mathrm{CH}_{2} \mathrm{OH}\right), 4.07\left(\mathrm{~d}, \mathrm{CH}_{2} \mathrm{OCO}\right)$.

FT-IR (KBr) : 2926, 1747, 1470, 1400, 1220, 1160, $1110,770 \mathrm{~cm}^{-1}$.

\section{RESULTS AND DISCUSSION}

When small (10\%) excess of dialkyl carbonate is used in transesterification with 1,3-diols, as was shown by Sarel et al., ${ }^{18}$ the reaction product contained significant amount of hydroxyl groups. During transesterification together with ethanol or methanol its carbonic acid ester is distilled off from the reaction mixture. To avoid the presence of a 1,3-diol monoester, which is difficult to remove from the post-reaction mixture and from the final cyclic product, the transesterification with 1,3-diols was carried out using a high excess of dialkyl carbonate to achieve complete conversion $\mathrm{OH}$ groups.

Using at least twofold excess (calculated for each $\mathrm{OH}$ group) of diethyl or dimethyl carbonate for the transesterification reaction with 1,3-diols $(\mathbf{1 a - 1 d})$ led to 1,3bis(alkoxycarbonyloxy)propanes (2a-2d) with 42-78\% yield (Table I) (Scheme 2).

The GC-MS analysis of the post-reaction mixture indicated the presence of the cyclic carbonate monomers $(\mathbf{3 a}$ -3e) as well as the linear dimers $(\mathbf{4 a}-\mathbf{4 d})$ and for smaller excess of carbonic acid ester also the linear trimers. The analysis of the products of the reaction 1c with diethyl carbonate (molar ratio $1: 3$ ) indicated that only small amount of 5-methyl-1,3-dioxan-2-one (3c) (7\%) was formed. The post-reaction mixture contained mainly 2ce $(25 \%)$, dimer 4ce (39\%) and trimer (26\%). For molar ratio $1: 8$ higher amount $(68 \%)$ of 2 ce was formed.

When dimethyl carbonate (bp $90^{\circ} \mathrm{C}$ ) was used and the reaction was carried out at lower temperature higher content of cyclic carbonate in the post-reaction mixture was observed (Table I).

It was found that significant influence on the product
Table I. The products obtained in the reaction of 1,3-diols (1) with carbonic acid esters

\begin{tabular}{|c|c|c|c|c|c|c|c|c|}
\hline \multirow{2}{*}{$\begin{array}{l}1,3- \\
\text { Diol }\end{array}$} & \multirow{2}{*}{$\begin{array}{l}\text { Molar ratio } \\
\mathrm{Et}_{2} \mathrm{CO}_{3} / \mathrm{OH}\end{array}$} & \multirow{2}{*}{$\frac{2}{w t \%}$} & \multirow{2}{*}{$\frac{\mathbf{3}}{\mathrm{wt} \%}$} & \multirow{2}{*}{$\frac{4}{w t \%}$} & \multirow{2}{*}{$\begin{array}{l}\text { Molar ratio } \\
\mathrm{Me}_{2} \mathrm{CO}_{3} / \mathrm{OH}\end{array}$} & \multirow{2}{*}{$\frac{2}{w t \%}$} & \multirow{2}{*}{$\frac{3}{w t \%}$} & \multirow{2}{*}{$\begin{array}{c}\mathbf{4} \\
\mathrm{wt} \%\end{array}$} \\
\hline & & & & & & & & \\
\hline $1 \mathbf{a}$ & 2.5 & 62 & 34 & 4 & 4 & 66 & 32 & 2 \\
\hline $1 b$ & 3 & 42 & 35 & $24^{a}$ & 4 & 73 & 24 & 3 \\
\hline $1 \mathrm{c}$ & 1.5 & 25 & 7 & $39^{b}$ & - & - & - & - \\
\hline $1 c$ & 2 & 56 & 34 & 10 & - & - & - & - \\
\hline $\mathbf{1 c}$ & 4 & 68 & 30 & 2 & 4 & 57 & 40 & 3 \\
\hline $1 \mathrm{c}$ & $4^{c}$ & 78 & 21 & 1 & $4^{c}$ & 77 & 22 & 1 \\
\hline $1 d$ & 4 & 51 & 32 & 11 & - & - & - & - \\
\hline $1 e$ & 2 & $<1$ & 99 & 0 & 4 & $<1$ & 99 & 0 \\
\hline $1 j^{d}$ & 2.5 & 5 & $95^{e}$ & 0 & 5 & $<2$ & $98^{\mathrm{e}}$ & \\
\hline
\end{tabular}

${ }^{a}$ The post-reaction mixture contained different dimer isomers. ${ }^{b}$ The post-reaction mixture contained $26 \%$ of trimer. "The reaction was carried out under reflux with subsequent alcohol distillation off. ${ }^{\mathrm{d}}$ Ethylene glycol. ${ }^{\mathrm{e}}$ Ethylene carbonate.

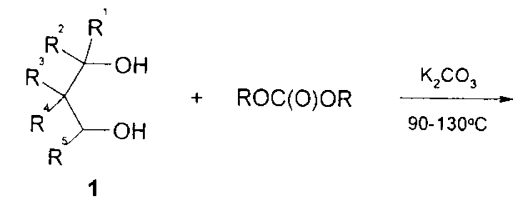

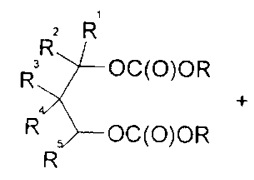

2

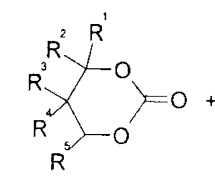

3

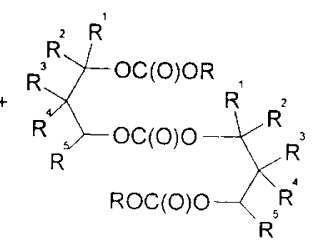

4
Scheme 2 .

composition had the rate of removing of alcohol during transesterification. For the reaction carried out for $8 \mathrm{~h}$ under reflux (under equilibrium conditions without alcohol removing) the post-reaction mixture was enriched with 1,3-bis(alkoxycarbonyloxy)propanes (2). It was also shown that no reaction between cyclic carbonate and dialkyl carbonate took place under the reaction conditions in the absence of free alcohol.

After removing an excess of diethyl carbonate the post-reaction mixture was additionally heated at $160^{\circ} \mathrm{C}$ for $2 \mathrm{~h}$ in the presence of $\mathrm{Sn}$ (II) carboxylate and due to polymerization of volatile cyclic carbonates pure 1,3-bis(ethoxycarbonyloxy)propanes (2ae-2de) could be isolated by the distillation.

In contrast, 2-methylpentane-2,4-diol (1e) subjected to transesterification with diethyl- or dimethyl carbonate led almost exclusively to six-membered cyclic carbonate 3e. Despite high molar excess of dialkyl carbonate (molar ratio $8: 1$ ) only small amount of linear carbonate derivatives were present in the post-reaction mixture. Three methyl substituents adjoining hydroxyl groups of 1,3-diol forced the conformation promoting cyclization (reaction $\mathbf{b}$ in Scheme 3). As one can deduce, 3e appeared to be inert in polymerization (Table IV). These results are very similar to those obtained by Matsuo et $a l .{ }^{23}$ The six-membered cyclic carbonate having aromatic substituents:5,5-diphenyl-1,3-dioxan-2-one showed 


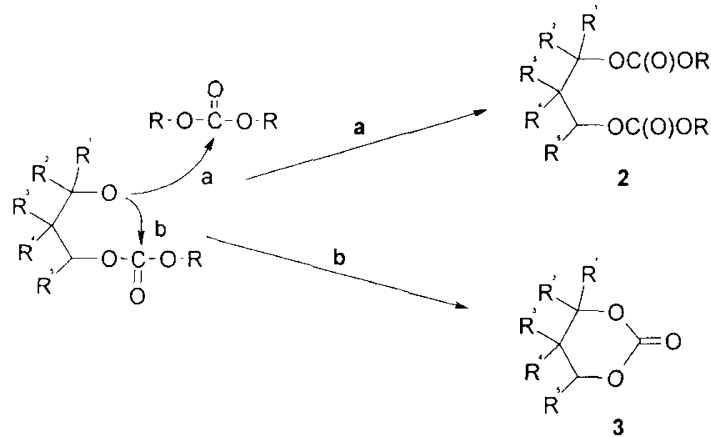

Scheme 3.

only a slight homopolymerizability, because of the conformational restriction of the adduct of 5,5-diphenyl-1,3dioxan-2-one with an alkoxide.

A similar reaction route was observed for ethylene glycol when even much larger excess (tenfold) of diethyl carbonate was used (Table I). In the post-reaction mixture mainly cyclic ethylene carbonate was present. Glycerol subjected to the reaction with the large excess of diethyl carbonate also gave five-membered cyclic carbonates with hydroxymethyl or ethoxycarbonyloxymethyl substituents as the main products (Table III).

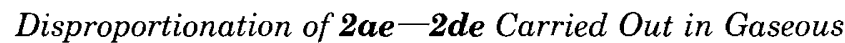 Phase}

1,3-bis(ethoxycarbonyloxy)propanes (2ae-2de) subjected to thermal catalytic disproportionation in gaseous phase at $250-350^{\circ} \mathrm{C}$ using $\mathrm{SiO}_{2}$ with surface of 200 $\mathrm{m}^{2} \mathrm{~g}^{-1}$ as a catalyst gave cyclic carbonates and diethyl carbonate as a by-product (Table II). The disproportionation was carried out using a column packed with $\mathrm{SiO}_{2}$ (LHSV $=2 \mathrm{~cm}^{3} \mathrm{~g}^{-1} \mathrm{~h}^{-1}$ ). The highest yields were obtained for $2 \mathrm{ce}\left(76 \%\right.$ at $\left.350^{\circ} \mathrm{C}\right)$. The lowest yields of cyclic carbonates was observed for butane-1,3-diol derivative (2be) (9\%), neopentylene (2de) (9\%) and trimethylene (2ae) $(<2 \%)$ glycol derivatives. It is characteristic that oligocarbonates obtained from those diols $(\mathbf{1 b}, \mathbf{1 d})$ thermally depolymerize giving cyclic carbonates with reasonable yields. ${ }^{21}$

For $\mathrm{V}_{2} \mathrm{O}_{5}(10 \mathrm{wt} \%) / \mathrm{Al}_{2} \mathrm{O}_{3}$ used as a catalyst, under the same conditions, higher conversion (100\%) was observed, but the yield of cyclic carbonate $(\mathbf{3 c})$ essentially dropped $\left(20 \%\right.$ at $\left.300^{\circ} \mathrm{C}\right)$. Similar effect was observed for $\mathrm{MoO}_{3}(10 \mathrm{wt} \%) / \mathrm{Al}_{2} \mathrm{O}_{3}$ used as a column bed, $14 \mathrm{wt} \%$ of $3 \mathbf{c}$ was obtained. It was in contrast to disproportionation of methyl phenyl carbonate, where $\mathrm{MoO}_{3} / \mathrm{SiO}_{2}$ showed a high activity and selectivity. ${ }^{15}$ It can be stated that for aliphatic carbonates higher acidity of the catalysts leads to higher conversion but selectivity of the process essentially decreases.

The disproportionation of 1,3-bis(ethoxycarbonyloxy)propanes can also be carried out in liquid phase in the presence of $\mathrm{Sn}(\mathrm{II})$ stearate or Aeorosil 200 (Table II). The yields of the cyclic carbonates were similar to those obtained from the gaseous phase method, but in the case of some 1,3-diols carbonate derivatives (2ae and 2be) prolonged contact time with catalyst led to higher yield of cyclic products. It should be emphasized that the
Table II. Catalytic disproportionation of $\mathbf{2 a e - 2 d e ^ { a }}$ in gaseous phase

\begin{tabular}{|c|c|c|c|c|}
\hline \multirow{2}{*}{ Carbonate } & \multirow{2}{*}{ Catalyst } & \multirow{2}{*}{$\frac{\text { Temp }}{{ }^{\circ} \mathrm{C}}$} & \multirow{2}{*}{$\begin{array}{l}\text { Conversion } \\
\text { of } 2 / \%\end{array}$} & \multirow{2}{*}{$\frac{\text { Yield of } \mathbf{3}}{\%}$} \\
\hline & & & & \\
\hline \multirow[t]{3}{*}{$2 \mathrm{ce}$} & $\mathrm{SiO}_{2}\left(200 \mathrm{~m}^{2} \mathrm{~g}^{-1}\right)$ & 250 & 38 & $30^{\mathrm{b}}$ \\
\hline & & 300 & 71 & 61 \\
\hline & & 350 & 86 & 76 \\
\hline \multirow[t]{3}{*}{$2 c e$} & $10 \mathrm{wt} \% \mathrm{~V}_{2} \mathrm{O}_{5} / \mathrm{Al}_{2} \mathrm{O}_{3}$ & 250 & 70 & 16 \\
\hline & & 300 & 55 & 20 \\
\hline & & 350 & 100 & $<2$ \\
\hline \multirow[t]{3}{*}{ 2ce } & $10 \mathrm{wt} \% \mathrm{MoO}_{3} / \mathrm{Al}_{2} \mathrm{O}_{3}$ & 250 & 100 & 11 \\
\hline & & 300 & 100 & 14 \\
\hline & & 350 & 100 & 2 \\
\hline \multirow[t]{3}{*}{$2 b e$} & $\mathrm{SiO}_{2}\left(200 \mathrm{~m}^{2} \mathrm{~g}^{-1}\right)$ & 250 & 25 & $3^{c}$ \\
\hline & & 300 & 36 & 5 \\
\hline & & 350 & 74 & 9 \\
\hline \multirow[t]{3}{*}{ 2de } & $\mathrm{SiO}_{2}\left(200 \mathrm{~m}^{2} \mathrm{~g}^{-1}\right)$ & 250 & 16 & $7^{\mathrm{d}}$ \\
\hline & & 300 & 38 & 9 \\
\hline & & 350 & 52 & 6 \\
\hline $2 \mathbf{a e}$ & $\mathrm{SiO}_{2}\left(200 \mathrm{~m}^{2} \mathrm{~g}^{-1}\right)$ & 250 & 46 & $<2^{e}$ \\
\hline
\end{tabular}

a Second letter means ethyl ester. ${ }^{\mathrm{b}}$ In the case of cyclic carbonate 3c obtained in liquid phase in the presence of Aerosil 200 at $190-220^{\circ} \mathrm{C}$ the yield was $44 \%$ (when $\mathrm{Sn}$ (II) stearate was used as a catalyst in liquid phase at $190-230^{\circ} \mathrm{C}$ the yield was $46 \%$ ). ${ }^{c}$ The yield of $\mathbf{3 b}$ obtained in liquid phase at $190-230^{\circ} \mathrm{C}$ was $18 \% .{ }^{\mathrm{d}}$ The yield of $3 \mathrm{~d}$ obtained in liquid phase at $190-230 \mathrm{C}$ was $12 \%$. " The yield of $3 \mathbf{a}$ obtained in liquid phase at $190-230^{\circ} \mathrm{C}$ was $7 \%$.

yields of these aliphatic bis(alkoxycarbonyloxy) derivatives disproportionation were lower than those of aromatic ones. The disproportionation of $2,2^{\prime}$-bis(methoxycarbonyloxy)biphenyl carried out in the presence of Sn (II) 2-ethylhexanoate at $280^{\circ} \mathrm{C}$ gave, as was shown by Kricheldorf et al., ${ }^{19}$ the aromatic cyclic carbonate with yield of $87 \%$.

\section{Two-Step Synthesis of Cyclic Carbonates}

1,3-Bis(ethoxycarbonyloxy)propanes (2) can also be used for the synthesis of cyclic carbonates in the twostep process. Thus, 2 was reacted with a stoichiometric amount of 1,3-diol (1) in the presence of tin (II) stearate. The condensation was carried out similarly to that reported by Gunatillake et al. ${ }^{24}$

In contrast to the typical method, due to much lower volatility of the 1,3-bis(ethoxycarbonyloxy)propanes (2) it was possible to keep correct stoichiometric equilibrium between 1,3-diol and carbonic acid esters during condensation (almost pure ethanol was removed by distillation). After complete conversion of $\mathrm{OH}$ groups the oligocarbonate was subjected to the distillative depolymerization leading to pure cyclic carbonate with the yield up to $80 \%$.

\section{Synthesis of Cyclic Carbonates from Tri- and Tetrafunc- tional Alcohols}

Typical method of distillative depolymerization of oligocarbonates is not suitable for obtaining of cyclic carbonates from polyfunctional alcohols because of possible crosslinking during transesterification with carbonic acid esters. It was shown that using more than four-fold 
Table III. Carbonates obtained in the reaction of polyols with carbonate acid esters

\begin{tabular}{|c|c|c|c|c|c|c|c|c|}
\hline \multirow{2}{*}{ Polyol } & Molar ratio & 2 & 3 & Dimer & Molar ratio & 2 & $\mathbf{3}$ & Dimer \\
\hline & $\mathrm{Et}_{2} \mathrm{CO}_{3} / \mathrm{OH}$ & $\overline{w t \%}$ & $\overline{\mathrm{wt} \%}$ & $\mathrm{wt} \%$ & $\mathrm{Me}_{2} \mathrm{CO}_{3} / \mathrm{OH}$ & $\overline{\mathrm{wt} \%}$ & $\overline{\mathrm{wt} \%}$ & wt $\%$ \\
\hline $1 k^{a}$ & 1.2 & $<1$ & $99^{b}$ & 0 & 1,2 & $<1$ & $99^{b}$ & 0 \\
\hline $1 f$ & 4 & 64 & 18 & 14 & 4 & 82 & 15 & 2 \\
\hline $1 \mathrm{f}$ & 6 & 76 & 11 & 13 & 12 & 86 & 11 & $<2$ \\
\hline $1 \mathrm{f}$ & 1.2 & - & - & $-{ }^{\mathrm{c}}$ & $2^{d}$ & 60 & - & $40^{\mathrm{e}}$ \\
\hline $1 \mathrm{~g}$ & - & - & - & - & 4 & 85 & 9 & $6^{\mathrm{f}}$ \\
\hline $1 \mathrm{~h}$ & - & - & - & - & 4 & 83 & 8 & $9^{f}$ \\
\hline
\end{tabular}

${ }^{\mathrm{a}}$ Glycerol. ${ }^{\mathrm{b}}$ Five-membered cyclic carbonate. ${ }^{\mathrm{c}}$ Crosslinked product. ${ }^{d}$ Reaction was carried out with fast methanol removing. ${ }^{\mathrm{e}}$ Polymer. ${ }^{\mathrm{f}}$ Oligomeric product.

excess of carbonic acid esters, calculated on each $\mathrm{OH}$ group, and when the first stage of the reaction was carried out without removing alcohol, tris- and tetrakis(alkoxycarbonyloxy) derivatives of polyalcohols $(\mathbf{2} \mathbf{f}-\mathbf{2 h})$ as the main products were obtained (Table III). The carbonate derivatives $\mathbf{2 f}-\mathbf{2 h}$ can be isolated by fractional distillation under reduced pressure. Subsequent disproportionation of $\mathbf{2 f}-\mathbf{2 h}$ carried out in liquid phase at 200 $220^{\circ} \mathrm{C}$ in the presence of Aerosil or $\mathrm{Sn}$ (II) stearate yielded oligocarbonates of TMP, TMP-dimer or pentaerythritol, respectively. The thermal depolymerization of the oligomers at $270-300^{\circ} \mathrm{C}$ carried out under reduced pressure $(0.05 \mathrm{mmHg})$ proceeds slowly and monocyclic (3f) or biscyclic carbonates $(\mathbf{3 g}$ and $\mathbf{3 h}$ ) were produced.

It was noticed, that for dimethyl carbonate, used in lower molar ratio $(4: 1)$, in the reaction with TMP, besides expected 1,1,1-tris(methoxycarbonyloxymethyl) propane (2fm) completely soluble polycarbonate [poly(3fm)] with methoxycarbonyloxymethyl pendant groups was formed (yield 40\%). In that experiment methanol was distilled off together with dimethyl carbonate at 80 $-100^{\circ} \mathrm{C}$ immediately after formation. When the transesterification was carried out under reflux for $10 \mathrm{~h}$, with subsequent methanol removing from the reaction mixture only small amount of high molecular poly(TMPcarbonate) was formed (Table III).

The MALDI-TOF mass spectrum of the polymeric product $[\operatorname{poly}(\mathbf{3 f m})]$ is presented in Figure 1. The most abundant peaks are characterized by a mass increment of $218 \mathrm{Da}$ from one peak to the next. This mass increment exactly equals the mass of the repeating unit in the poly(2-ethyl-2-methoxycarbonyloxymethylpropane1,3-diol carbonate) $[$ poly $(\mathbf{3 f m})]$. The difference between the main series is $90 \mathrm{Da}$. The most abundant series of peaks $\left(M_{n}=2079 \mathrm{Da}\right)$ corresponds to polycarbonate with four methoxycarbonyloxy end groups (residual mass equal $90 \mathrm{Da})$. The second series of peaks $\left(M_{n}=2297 \mathrm{Da}\right)$ correspond to poly $(\mathbf{3 f m})$ molecules with one 1,3-dioxan2 -one and two methoxycarbonyloxy end groups. The third series (less than $2 \%$ ) correspond to poly $(3 \mathbf{f m})$ with two 1,3-dioxan-2-one end groups. Considerably high molecular weight $\left(M_{n}=2408 \mathrm{Da}, M_{w} / M_{n}=1.17\right)$ of $\operatorname{poly}(\mathbf{3 f m})$ means that for the methylcarbonate derivatives of TMP the linear structure is preferred and cyclic carbonate of TMP (3f) can be easily isolated by the distillative depolymerization. The similar cyclic carbonate derivative,

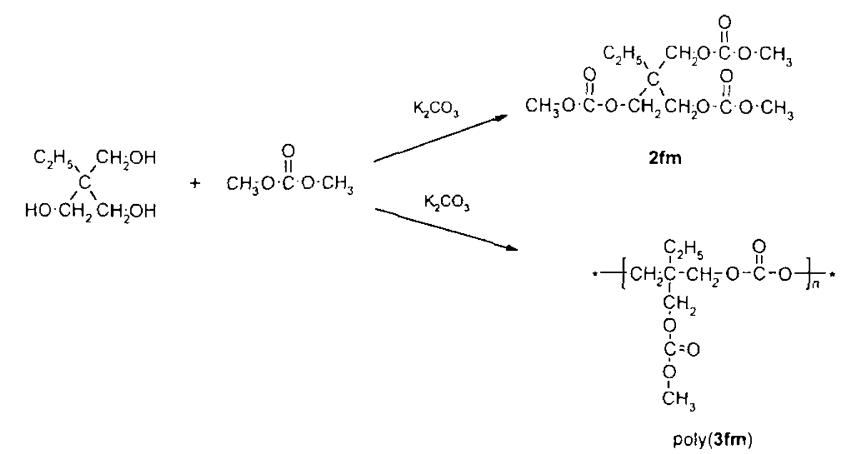

Scheme 4 .

Table IV. Polymerization of 1,3-dioxan-2-ones in bulk in the presence of different catalysts

\begin{tabular}{|c|c|c|c|c|c|c|c|}
\hline \multirow{2}{*}{$\begin{array}{c}\text { Cyclic } \\
\text { carbonate }\end{array}$} & \multirow{2}{*}{ Initiator } & \multirow{2}{*}{$\frac{\text { Initiator }}{\text { mol\% }}$} & \multirow{2}{*}{$\frac{\text { Temp }}{{ }^{\circ} \mathrm{C}}$} & \multirow{2}{*}{$M_{n}$} & \multirow{2}{*}{$M_{w}$} & \multirow{2}{*}{$M_{w} / M_{n}^{\mathrm{a}}$} & \multirow{2}{*}{$\begin{array}{l}\text { Polymer } \\
\text { yield } / \%\end{array}$} \\
\hline & & & & & & & \\
\hline \multirow[t]{4}{*}{$\mathbf{3 c}$} & $\mathrm{BF}_{3} \cdot \mathrm{OEt}_{2}$ & 0.7 & 80 & 4800 & 5900 & 1.23 & 88 \\
\hline & $\mathrm{BF}_{3} \cdot \mathrm{OEt}_{2}$ & 1 & 80 & 2200 & 2500 & 1.13 & 69 \\
\hline & SnOct $_{2}$ & 1 & 100 & 1950 & 2200 & 1.12 & 76 \\
\hline & Lipase & 1 & 60 & 2330 & 2790 & 1.20 & 56 \\
\hline \multirow[t]{2}{*}{$\mathbf{3 d}$} & SnOct $_{2}$ & 0.7 & 120 & 2930 & 3320 & 1.13 & $42.5^{\mathrm{a}}$ \\
\hline & $\mathrm{SnOct}_{2}$ & 0.7 & 120 & 1580 & 1850 & 1.17 & $57.5^{\mathrm{b}}$ \\
\hline \multirow[t]{3}{*}{$\mathbf{3 e}$} & $\mathrm{BF}_{3} \cdot \mathrm{OEt}_{2}$ & 1 & 120 & - & - & - & $-^{d}$ \\
\hline & SnOct $_{2}$ & 1 & 120 & - & - & - & $-d$ \\
\hline & Lipase & 1 & 60 & - & - & - & $-d$ \\
\hline \multirow[t]{3}{*}{$3 \mathrm{fm}$} & $\mathrm{BF}_{3} \cdot \mathrm{OEt}_{2}$ & 1 & 100 & - & - & - & $-{ }^{d}$ \\
\hline & $\mathrm{BF}_{3} \cdot \mathrm{OEt}_{2}$ & 1 & 120 & $-{ }^{c}$ & - & - & $-{ }^{\mathrm{c}}$ \\
\hline & $\mathrm{K}_{2} \mathrm{CO}_{3}$ & 1.2 & 120 & 2540 & 2880 & 1.23 & 69 \\
\hline
\end{tabular}

${ }^{a}$ Determined by MALDI-TOF. ${ }^{b}$ Linear product. ${ }^{c}$ Cyclic product. ${ }^{\mathrm{d}}$ Crosslinked product. ${ }^{\mathrm{e}}$ No polymer was obtained.

but containing benzyloxycarbonyloxymethyl group, was obtained by Kühling et al. from 5-ethyl-5hydroxymethyl-1,3-dioxan-2-one and benzyl chloroformate. The polymerization of this cyclic carbonate initiated by $s$-butyllithium leads to polycarbonate with benzyloxycarbonyloxymethyl pendant groups. ${ }^{25}$

The yield of cyclic carbonates significantly dropped when tetrafunctional derivatives $\mathbf{2 g}-\mathbf{2 h}$ were used. As it could be predicted, the probability of double cyclization of the trimethylolpropane dimer and pentaerythritol carbonate derivatives without polymerization one of the rings was rather low (Table III).

\section{Polymerization of 1,3-Dioxan-2-ones}

5-Methyl-1,3-dioxan-2-one (3c) obtained according to the disproportionation procedure was polymerized using $\mathrm{BF}_{3} \cdot \mathrm{OEt}_{2}, \mathrm{SnOct}_{2}$ and enzymatic (Candida Antarctica lipase) catalysts (Table IV). The polycarbonates obtained in the presence of acidic catalyst $\left(\mathrm{BF}_{3} \cdot \mathrm{OEt}_{2}\right)$, as earlier was found for other cyclic carbonates, ${ }^{21,26,27}$ contained small amount (ca.4-5\%) of ether linkages formed by partial elimination of $\mathrm{CO}_{2}$. The ether content was determined by ${ }^{1} \mathrm{H}$ NMR spectroscopy $\left(3.31, \mathrm{~d}, \mathrm{CH}_{2} \mathrm{OCH}_{2}\right.$, and $0.95 \mathrm{ppm}, \mathrm{d}, \mathrm{CH}_{3}$ ).

In the MALDI-TOF mass spectrum of $\operatorname{poly}(\mathbf{3 c})$ obtained using $\mathrm{BF}_{3} \cdot \mathrm{OEt}_{2}$ catalyst (Figure 2) four series of 


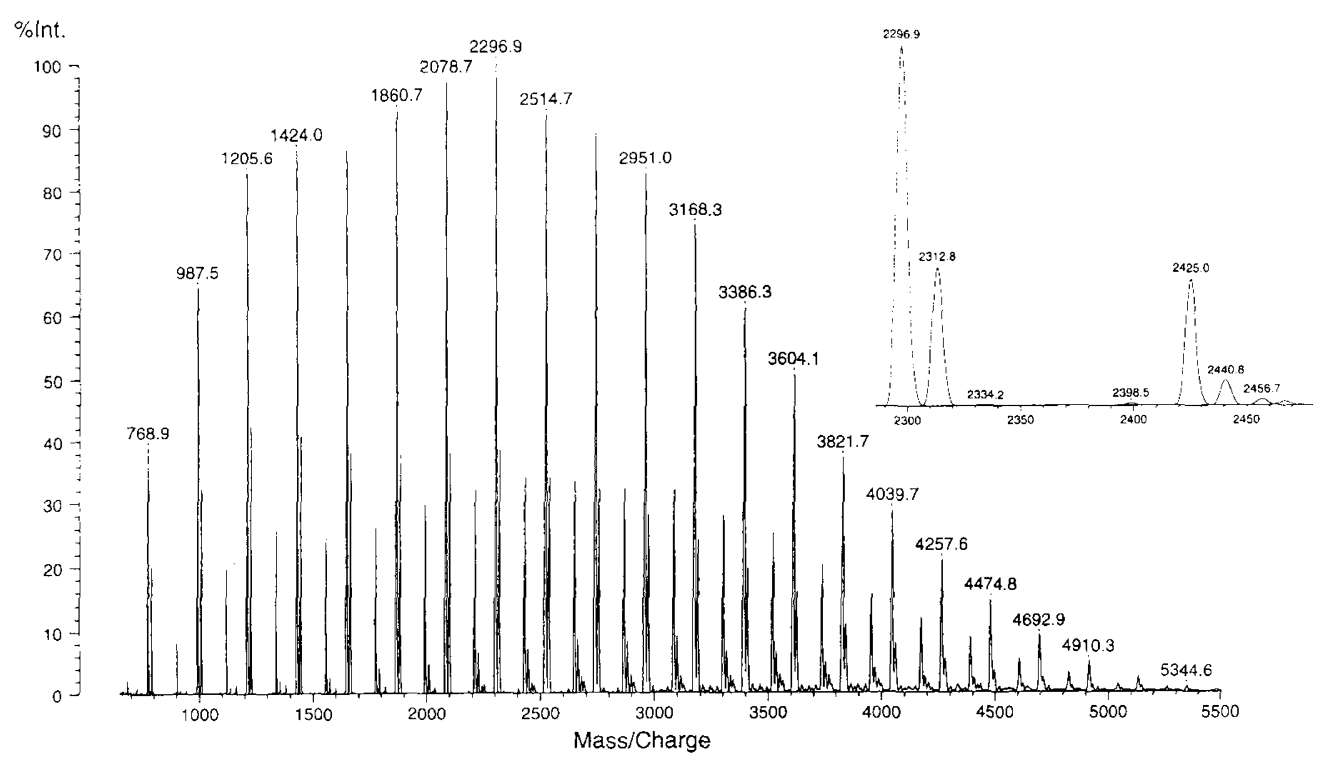

Figure 1. MALDI TOF mass spectrum of the polymeric product [poly(2-ethyl-2-methoxycarbonyloxymethylpropane-1,3-diol carbonate)] of the reaction of 1 with dimethyl carbonate (molar ratio $1: 5$ ) carried out with fast methanol removing from the system. Conditions : $\mathrm{K}_{2} \mathrm{CO}_{3}$ $0.8 \mathrm{~mol} \%, 85-100^{\circ} \mathrm{C}$.

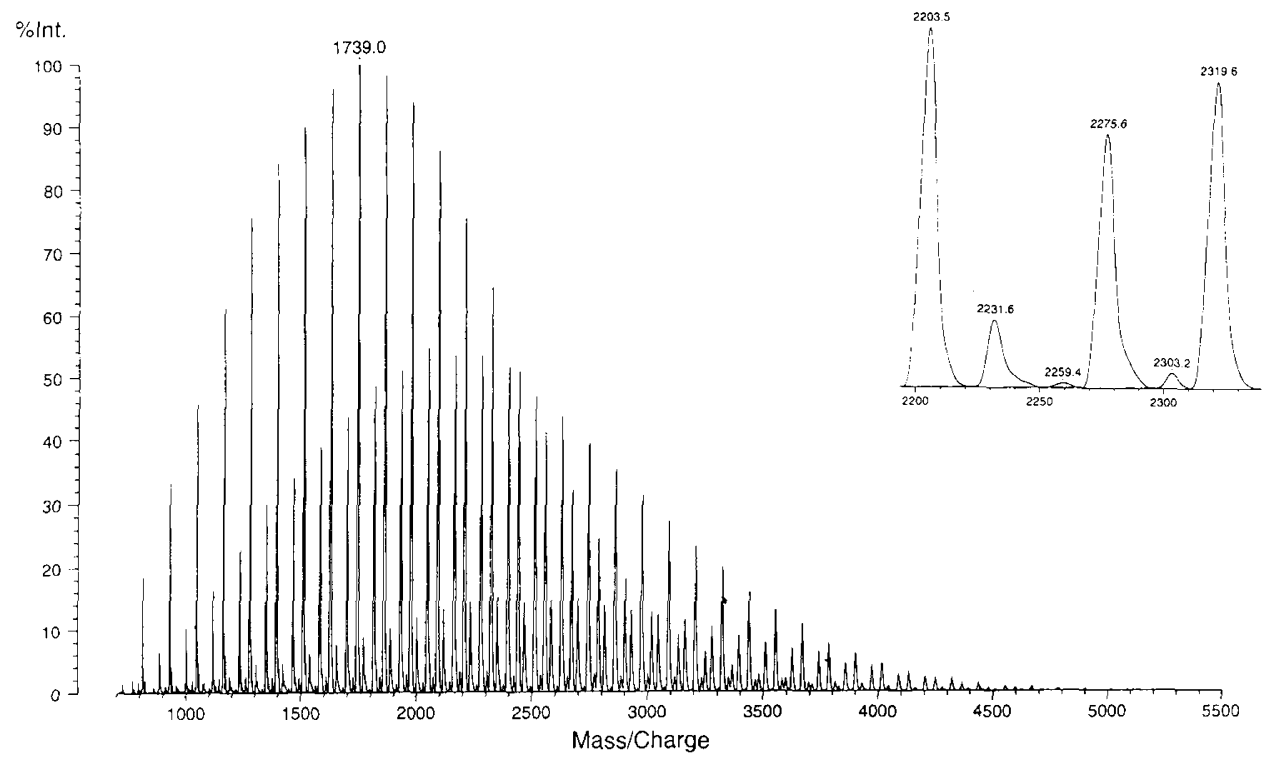

Figure 2. MALDI TOF mass spectrum of the polymerization product of $3 \mathbf{c}$ initiated by $\mathrm{BF}_{3} \cdot \mathrm{OEt}_{2}$. Conditions : $\mathrm{BF}_{3} \cdot \mathrm{OEt}_{2} 1 \mathrm{~mol}^{2}, 80^{\circ} \mathrm{C}, 40$ $\mathrm{h}$ in bulk.

peaks of high intensity are present together with a number of peaks of lower intensity. The most abundant peaks are characterized by a mass increment of $116 \mathrm{Da}$ from one peak to the next. This mass increment exactly equals the mass of the repeating unit in the poly(2methylpropane-1,3-diol carbonate). The difference between the main series is $44 \mathrm{Da}$. The most abundant series of peaks $\left(M_{n}=1855 \mathrm{Da}\right)$ corresponds to polycarbonate with 2-methylpropane-1,3-diol as the end groups (residual mass equal $90 \mathrm{Da})$. Second series of peaks $\left(M_{n}=2276\right.$ Da) corresponds to polycarbonate molecules with one ether linkage (residual mass : $46 \mathrm{Da}$ ). It means that one molecule of $\mathrm{CO}_{2}$ was lost for each polymer molecule of that series. Third series $\left(M_{n}=2644 \mathrm{Da}\right)$ with two, forth series $\left(M_{n}=2390 \mathrm{Da}\right)$ with three and fifth series $\left(M_{n}=\right.$ $2100 \mathrm{Da})$ with four ether linkages per each polymer molecule were present. Taking into consideration that the series peak area is equivalent to concentration the relative amounts of the five fractions are calculated to be $49: 37: 11: 2: 0.5$. From these results it can be stated that for example in the second series for 19 carbonate linkages in a macromolecule one ether linkage was present, on the average.

Although cationic ring-opening polymerization of 3c yielded the polymer with $\mathrm{OH}$ end groups the presence of segments with ether linkages susceptible to oxidation makes this method inconvenient for polyurethane polyols preparation, especially those for medical application, where contact with blood is possible.

When the catalyst of coordination polymerizationSnOct $_{2}$ was used the resulting product consisted of polycarbonate with $\mathrm{OH}$ and isooctyl (origin from the cata- 


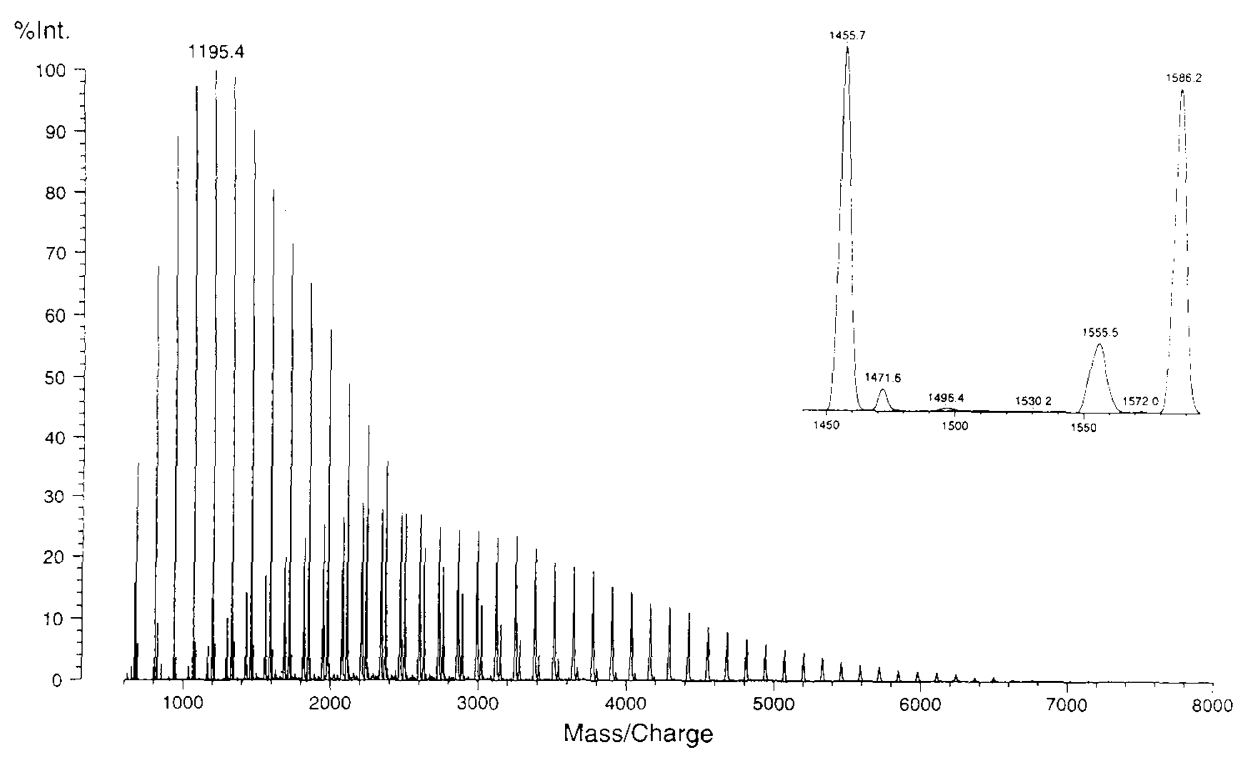

Figure 3. MALDI TOF mass spectrum of the polymerization product of $3 d$ initiated by SnOct 2 . Conditions : SnOct $20.7 \mathrm{~mol}_{2} \%, 120^{\circ} \mathrm{C}, 24 \mathrm{~h}$ in bulk.

lyst) end groups and the oligomeric cycles. In Figure 3 the MALDI-TOF mass spectrum of poly(3d) obtained in the presence of $\mathrm{SnOct}_{2}$ is shown. Two series of peaks are present. The difference between the series is $230 \mathrm{Da}$. For both mass increment exactly equals the mass of the repeating unit (130 Da) in poly $(\mathbf{3 d})$. The most abundant series of peaks $\left(M_{n}=1580 \mathrm{Da}\right)$ corresponds to oligomeric cycles. Second series of peaks $\left(M_{n}=2934 \mathrm{Da}\right)$ corresponds to polycarbonate molecules with isooctyl and hydroxyl end groups (residual mass: $100 \mathrm{Da}$ ). The relative amounts of the two fractions are calculated to be 57.5 : 42.5. Similar results, where oligocycles were present, but in a lower concentration were reported by Penczek and $\mathrm{Duda}^{28}$ for ring opening polymerization of $\varepsilon$-lactone in the presence of SnOct $\mathrm{S}_{2}$.

For enzymatic polymerization of 3c (Table IV) no decarboxylation was observed under mild conditions (60 $\left.{ }^{\circ} \mathrm{C}\right)$. The structural differences between the monomer and polymer is derived from the presence of diastereotopic protons of the adjacent methylene groups of the quaternary carbon atom of the monomer. Thus, the axial and equatorial hydrogen atoms of the methylene groups are not magnetically equivalent and they show doublet of doublets in the ${ }^{1} \mathrm{H}$ NMR spectrum. In the polymer methylene groups can freely rotate and show only doublet.

In the MALDI-TOF mass spectrum the most abundant population of macromolecules with hydroxyl end groups, being apart by $\mathrm{Da}=116$ (molar mass of $3 \mathrm{c}$ ) was observed (Figure 4).

\section{Polymerization of 5-Ethyl-5-Methoxycarbonyloxymethyl-1, 3-dioxan-2-one}

The $3 \mathrm{gm}$ was polymerized in the presence of $\mathrm{K}_{2} \mathrm{CO}_{3}$ yielding the polymer with methoxycarbonyloxymethyl pendant groups. It was found that there was no significant transesterification between the raising chain and the pendant carbonate groups. The structure of the polymer was similar to that of polycarbonate formed during the reaction of dimethyl carbonate with TMP with fast removing methanol from the reaction system (Figures 1 and 5). The unimodal molecular weight distribution of poly $(\mathbf{3 f m})$ macromolecules indicated linear chemical structure of the polymer. In contrast to the monomer (3fm), in the ${ }^{1} \mathrm{H}$ NMR spectrum of poly $(\mathbf{3 f m})$ only one singlet for $\mathrm{CH}_{2} \mathrm{OC}(\mathrm{O}) \mathrm{O}$ groups $(4.11 \mathrm{ppm})$ was present. The quaternary carbon atom of the monomer is pseudoasymmetric and the protons of the four adjacent methylene groups are diastereotopic, similarly to those of $\mathbf{3 c}$. The two exocyclic methylene groups can rotate and therefore, the hydrogen atoms are magnetically equivalent. The free rotation of two methylene groups in the carbonate cycle is restricted, so that only conformation changes can take place. Thus, axial and equatorial hydrogen atoms are magnetically different and they exhibit two doublets $(J=10 \mathrm{~Hz})$. In the polymer methylene groups can rotate and there is only singlet in the ${ }^{1} \mathrm{H}$ NMR spectrum.

It was also found that in the presence of $\mathrm{BF}_{3} \cdot \mathrm{OEt}_{2}$ no polymer was formed at temperature below $100^{\circ} \mathrm{C}$. At higher temperature $\left(120^{\circ} \mathrm{C}\right) \mathrm{CO}_{2}$ elimination was observed, which led to the product with ether linkages and the crosslinked product was formed.

\section{CONCLUSIONS}

It was shown that depending on a chemical structure thermal disproportionation of 1,3-bis(alkoxycarbonyloxy)propanes or distillative depolymerization of oligocarbonates obtained from 1,3-bis(alkoxycarbonyloxy)propanes and 1,3-dioles could be applied for the synthesis of cyclic carbonates. The presence of three methyl substituents forced the 1,3-diol in the reaction with carbonic esters exclusively to the cyclic structure.

The new six-membered cyclic carbonate with 5-ethyl and 5-alkoxycarbonyloxymethyl substituents (3f) at the 1,3-dioxane-2-one ring could be obtained by thermal disproportionation and two step methods. The cyclic car- 


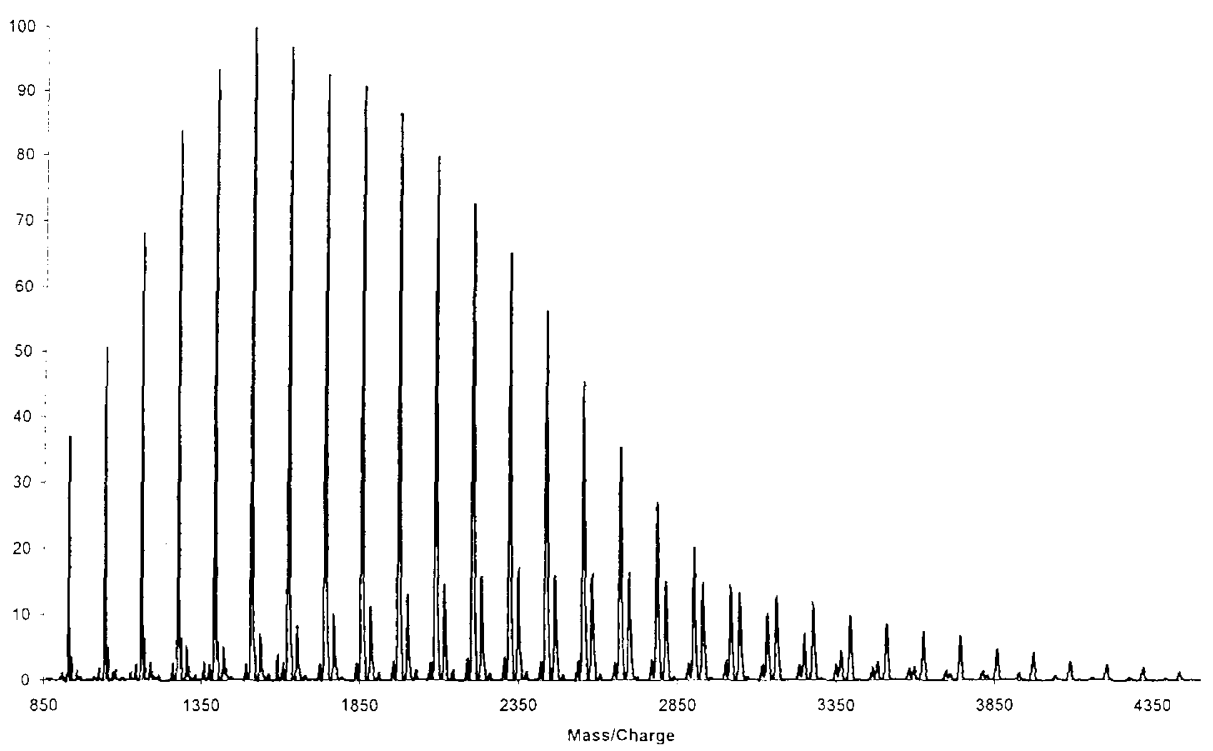

Figure 4. MALDI TOF mass spectrum of the poly(3e) obtained in enzymatic polymerization using Novozym lipase. Conditions : $1 \%$ concentration of immobilized lipase (corresponds to approximately $0.05 \%$ lipase) based on a monomer, $60^{\circ} \mathrm{C}, 120 \mathrm{~h}$ in bulk.
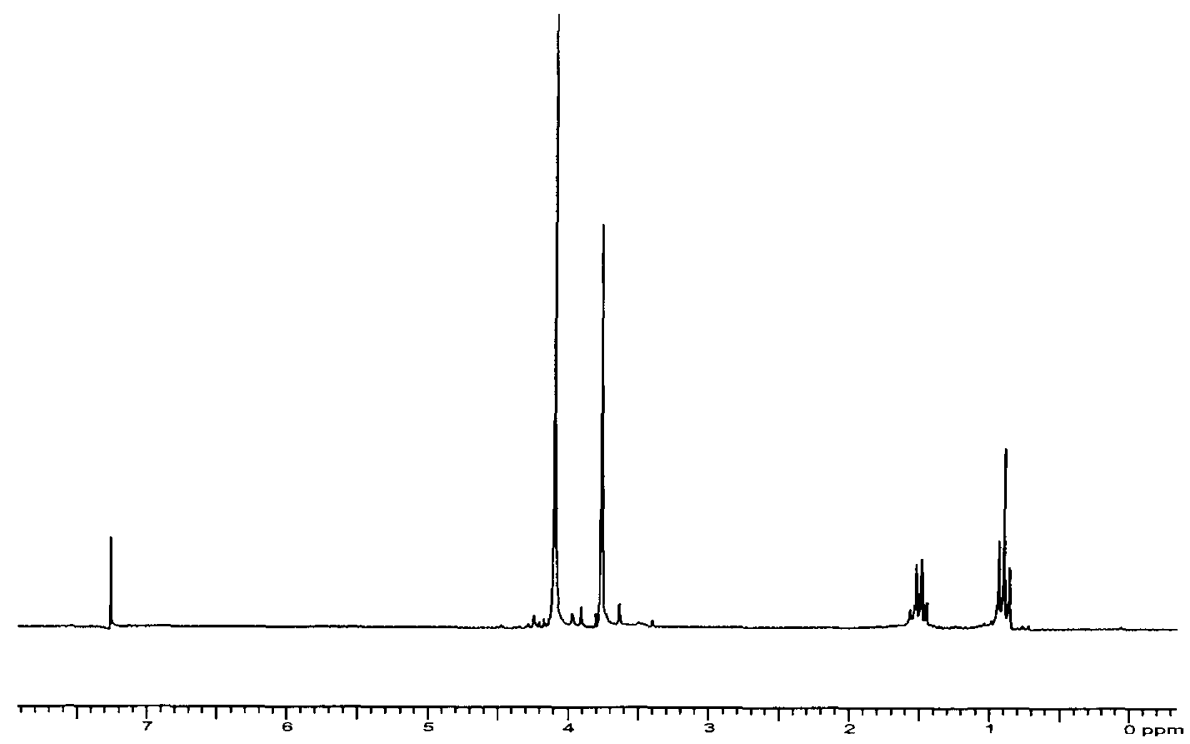

Figure 5. ${ }^{1} \mathrm{H}$ NMR spectrum $\left(200 \mathrm{MHz}, \mathrm{CDCl}_{3}\right.$ ) of poly(2-ethyl-2-methoxycarbonyloxymethylpropane-1,3-diol carbonate) obtained in the presence of $\mathrm{K}_{2} \mathrm{CO}_{3}(1.2 \mathrm{~mol} \%)$ at $120^{\circ} \mathrm{C}$.

bonate 3f polymerized with anionic catalyst yielded the linear polycarbonate with alkylcarbonate pendant groups and no crosslinked product was observed.

Acknowledgment. This work was supported financially by the KBN grant 3 T09B 11512 .

\section{REFERENCES}

1. W. Kuran, Prog. Polym. Sci. 23, 919 (1998).

2. D. J. Brunelle, in "Ring-Opening Polymerization", Hanser Verlag, Munich, 1993, p 309.

3. H. Höcker and H. Keul, 'Cyclic Carbonates (Ring-Opening Polymerization)', in "Polymeric Materials Encyclopedia" Vol.2, J.C. Salomone, Ed., CRC Press, Boca Raton, 1996, pp 1647-1654.

4. K. Stokes, R. McVenes, and J.M. Anderson, J. Biomater.
Appl., 9, $321(1995)$.

5. R. J. Zdrahala, J. Biomater. Appl., 11, 37 (1996).

6. L. Pinchuk, J. B. Martin, M. C. Esuivel, and D. C. MacGregor, J. Biomater. Appl. 3, 260 (1988).

7. H. Keul, A. J. Müller, and H. Höcker, Makromol. Chem., Macromol. Symp., 67, 289 (1993).

8. T. Takata and T. Endo, Prog. Polym. Sci., 18, 839 (1993).

9. W. J. Bailey, K. No, C.-Y. Pan, K. Saigo, J. Stansbury, S.-R. Tan, and J. Zhou, Polym. Prepr., Am. Chem. Soc., Div. Polym, Chem., 26, 50 (1986).

10. W. J. Bailey, M. J. Amone, B. Issari, Y.-N. Lin, K. No, C.-Y. Pan, K. Saigo, J. Stansbury, S.-R. Tan, C. Wu, N. Yamazaki, and J. Zhou, J. Am. Chem. Soc., Div. Polym. Mater., Prepr., 54, 23 (1986).

11. T. Takata, F. Sanda, T. Ariga, H. Nemoto, and T. Endo, Macromolecular Rapid Commun., 18, 461 (1997).

12. T. Takasaki, F. Sanda, and T. Endo, Polym. Prepr., Am. Chem. Soc., Div. Polym. Chem., 40, 82 (1999). 
13. D. J. Brunelle and T. G. Shannon, Macromolecules, 24, 3035 (1991).

14. J. Matsuo, K. Aoki, F. Sanda, and T. Endo, Macromolecules, 31, 4432 (1998).

15. Y. Ono, Pure Appl. Chem., 68, 367 (1996).

16. S. Sarel and L. A. Pohoryles, J. Am. Chem. Soc., 80, 4596 (1958).

17. S. Sarel, L. A. Pohoryles, and R. Ben-Shoshan, J. Org. Chem., 24, 1873 (1959).

18. H. R. Kricheldorf, S. R. Lee, and B. Weegenschulz, Macromol. Chem. Physics, 197, 1043 (1996).

19. H. R. Kricheldorf and J. Jenssen, Eur. Polym. J., 25, 1273 (1989).

20. K. Pihlaja and K. Rossi, Acta Chem. Scand., B37, 289 (1983).

21. A.-C. Albertsson and M. Sjoeling, J. M. S. Pure Appl. Chem.,
A29, 43 (1992)

22. H. Krimm, H-J. Buysh, and H. Schnell, Pat. USA 4054597 (1977).

23. J. Matsuo, F. Sanda, and T. Endo, Macromol. Chem. Physics, 199,2489 (1998).

24. P. A. Gunatillake, G. F. Meijs, S. J. Mccarthy, R. Adhikari, and N. Sherriff, J. Appl. Polym. Sci., 69, 1621 (1998).

25. S. Kühling, H. Keul, and H. Höcker, Makromol. Chem. 192 1193 (1991)

26. H. R. Kricheldorf and J. Jenssen, J. Macromol. Sci., Pure Appl. Chem., A26, 631 (1989).

27. H. R. Kricheldorf, R. Dunsing, and A. Serra, Makromol. Chem., 188, 2453 (1987).

28. A. Kowalski, J. Libiszowski, A. Duda, and S. Penczek, Polym. Prepr., Am. Chem. Soc., Div. Polym. Chem., 39, 74 (1998). 